\title{
Analisis Produktivitas dan Pendapatan Petambak Garam di Kabupaten Jeneponto Provinsi Sulawesi Selatan
}

\section{Analysis of Productivity and Income of Salt Farmers in Jeneponto Regency, South Sulawesi Province}

\author{
B. Aswar Leo ${ }^{1}$, Sri Suro Adhwati ${ }^{2}$, Aslina Asnawi ${ }^{3}$
}

${ }^{1}$ Magister Agribisnis Sekolah Pascasarjana Universitas Hasanuddin

${ }^{2}$ Departemen Sosial Ekonomi Perikanan Universitas Hasanuddin

${ }^{3}$ Departemen Sosial Ekonomi Peternakan Universitas Hasanuddin

E-mail: $\underline{\text { aswarleo1771@gmail.com }}$

\begin{abstract}
Abstrak
Peningkatan produktivitas garam dapat dilakukan dengan cara mengoptimalkan faktor produksi garam. Pada umumnya, produksi berbanding lurus dengan penerimaan yang juga akan berpengaruh pada pendapatan. Semakin meningkat output produksi yang dihasilkan maka semakin meningkat penerimaan petambak tersebut dengan asumsi harga garam tidak mengalami penurunan. Faktor harga merupakan hal yang sulit dikendalikan petambak. Biasanya harga garam ditentukan oleh pasar atau harga yang telah ditetapkan sehingga petambak hanya bisa berusaha dalam meningkatkan produksi yang dihasilkan. Permasalahan yang terjadi mengakibatkan perubahan pada pendapatan petambak. Oleh karena itu diperlukan penelitian yang dapat membuktikan bahwa apakah faktor produksitivitas mempengaruhi pendapatan petambak garam di Kabupaten Jeneponto Provinsi Sulawesi Selatan. Tujuan yang akan dicapai pada penelitian ini adalah Mengetahui apakah ada hubungan antara produktivitas dan pendapatan petambak di Kabupaten Jeneponto. Hasil peneitian diperoleh informasi nilai korelasi person antara variabel produktivitas dengan variabel pendapatan sebesar 0.728. Oleh karena nilai korelasi berada di range 0.60 - 0.799 maka dapat disimpulkan bahwa hubungan antara variabel produktivitas dengan variabel pendapatan adalah kuat.
\end{abstract}

Kata Kunci: Produktivitas; Produksi; Pendapatan; Harga; Garam

\section{Pendahuluan}

Indonesia memiliki 17.508 pulau sehingga dijuluki Indonesia memiliki 17.508 pulau sehingga dijuluki negara kepulauan yang memiliki batas laut dan daratan yang luas. Indonesia dikenal sebagai negara dengan garis pantai terpanjang kedua dunia yakni 99.093 kilometer. Hal ini merupakan potensi sangat besar yang dimiliki oleh Indonesia untuk dapat memproduksi garam secara maksimal dan juga mampu menjadi negara sebagai sentra penghasil garam di Dunia. Tetapi kenyataannya berbanding terbalik dengan kondisi yang ada, hanya 26.024 hektar yang dapat dijadikan lokasi tambak garam. Hal tersebut dipengaruhi oleh beberapa faktor fisik diantaranya meliputi topografi, klimatologi, dan salinitas, dan juga dipengaruhi oleh faktor sosial yaitu budaya masyarakat sekitar (Wirawan, 2017).

Wilayah pesisir memiliki keragaman potensi sumber daya alam yang tinggi dan sangat penting bagi pengembangan sosial, ekonomi, budaya dan lingkungan, sehingga perlu dikelola secara berkelanjutan agar memiliki kontribusi ekonomi pada rumah tangga perikanan. Di Indonesia komoditi perikanan sebagian besar masih merupakan perikanan rakyat, dan hanya sebagian kecil merupakan perikanan industri. Perikanan rakyat hingga saat ini masih bersifat sangat tradisional, artinya pengolahan yang dilakukan oleh masyarakat yang menggunakan peralatan yang sangat sederhana. Dimana masyarakat belum banyak menerima atau menerapkan informasi dari luar yang lebih modern, (Wiryati G, dkk, 2019).

Garam telah menjadi komoditas strategis nasional yang memiliki fungsi yang tidak kalah penting dari kebutuhan pokok lainnya dikarenakan peran dan fungsi garam sangat penting bagi kehidupan masyarakat. Garam memiliki fungsi untuk sumber sodium dan juga sebagai chloride, dimana kedua unsur diperlukan dalam tubuh manusia sebagai proses metabolisme, (Saga N, dkk, 2019). Hal itu dikarenakan menyangkut kepentingan bangsa dan semua orang mengkonsumsinya, selain itu garam juga dibutuhkan oleh industri-industri pengolahan yang ada di Indonesia, Sehingga komoditas garam menjadi salah satu komoditas strategis yang serat dengan campur tangan pemerintah dan sangat diperhatikan keberlanjutannya, (Astitik, dkk, 2019).

Berdasarkan data Dinas Kelautan dan Perikanan Sulawesi Selatan, (2020), Provinsi Sulawesi Selatan memiliki lima Kabupaten yang memproduksi garam rakyat. Dimana pada tahun 2019, Kabupaten Jeneponto memproduksi 71,956.32 ton, Kabupaten Pangkajene dan Kepulauan (Pangkep) memproduksi 45,719.98 ton, Kabupaten Takalar sebanyak 22,358.86 ton Kabupaten Kepulauan Selayar memproduksi 156.21 ton dan Kabupaten Maros memproduksi 147.50 ton. Bahkan, jika produksi garam di Kabupaten Jeneponto bisa mencapai 71,956.32 ton per tahun, maka daerah ini akan menjadi daerah penghasil garam terbesar di Indonesia.

Berbagai macam persoalan yang timbul dalam pemenuhan kebutuhan garam, persoalan yang terjadi 
khususnya di Kabupaten Jeneponto tidak terlepas dari masalah Produktivitas. Produksi garam di Kabupaten Jeneponto mengalami pasang surut. Penurunan produksi sangat dipengaruhi oleh berbagai faktor, yakni faktor cuaca, proses produksi yang dilakukan yang masih sederhana dengan mengandalkan panas matahari dengan kata lain melakukan pengkristalan air laut untuk menjadi garam, proses distribusi yang belum optimal, kapabilitas sumber daya manusianya yang rendah dan masih banyak lagi permasalahan yang menyebabkan produksi garam menurun.

Daerah sentra garam dan telah memproduksi garam yang relatif banyak namun hampir tidak pernah kita dengar kisah sukses seorang petambak garam di Kabupaten Jeneponto. Kecamatan Bangkala dan Kecamatan Arungkeke merupakan sentra produksi garam di Kabupaten Jeneponto. Dari tahun ke tahun di dua kecamatan tersebut masih di jumpai petambak garam yang menjual garamnya di pinggir jalan. Metode pemasaran seperti ini sebagaimana kita ketahui merupakan metode pemasaran yang paling sederhana. Produk yang dihasilkan langsung ditawarkan di tempat tanpa adanya nilai tambah yang dihasilkan, sehingga tingkat keuntungan yang meraka dapatkan tidak maksimal.

Peningkatan produksi garam dapat dilakukan dengan cara mengoptimalkan faktor produksi garam. Pada umumnya, produksi berbanding lurus dengan penerimaan yang juga akan berpengaruh pada pendapatan. Semakin meningkat output produksi yang dihasilkan maka semakin meningkat penerimaan petambak tersebut dengan asumsi harga garam tidak mengalami penurunan. Faktor harga merupakan hal yang sulit dikendalikan petambak. Biasanya harga garam ditentukan oleh pasar atau harga yang telah ditetapkan sehingga petambak hanya bisa berusaha dalam meningkatkan produksi yang dihasilkan. Permasalahn tersebut berakibat pada perubahan pendapatan petambak sehingga diperlukan penelitian untuk membuktikan adanya hubunga antara produktivitas dengan pendapatan petambak di Kabupaten Jeneponto Provinsi Sulawesi Selatan.

\section{Metode Penelitian}

Penelitian ini dilakukan di dua Kecamatan yang berada di Kabupaten Jeneponto, Provinsi Sulawesi Selatan yaitu Kecamatan Arungkeke dan Kecamatan Bangkala. Pemilihan lokasi dilakukan secara sengaja (purposive) dengan pertimbangan bahwa daerah tersebut merupakan sentra produksi garam dan memiliki potensi pengembangan usaha garam di Kabupaten Jeneponto, Sulawesi Selatan. Adapun waktu pelaksanaan penelitian ini selama bulan April sampai bulan Juni 2020.

Metode yang digunakan untuk mngetahui adanya hubungan antara produktivitas dan pendapatan petambak garam di Kabupaten Jeneponto Sulawesi Selatan dapat menggunakan rumus Analisis Korelasi Pearson. Analisis korelasi person digunakan untuk mengetaahui hubungan antara satu variabel dengan variabel lainnya secara linier. Menurut Sugiyono (2013), penentuan koefisien korelasi dengan menggunakan metode analisis korelasi pearson dengan menggunakan rumus sebagai berikut:

$$
r_{x y}=\frac{n \sum x_{i} y_{i}-\left(\sum x_{i}\right)\left(\sum y_{i}\right)}{\sqrt{\left\{n \sum x_{i}{ }^{2}-\left(\sum x_{i}\right)^{2}\right\}-\left\{n \sum y_{i}{ }^{2}-\left(\sum y_{i}\right)^{2}\right\}}}
$$

Keterangan:

$\mathrm{r}_{\mathrm{xy}}=$ Koefisien Korelasi pearson

$\mathrm{x}_{\mathrm{i}} \quad=$ Variabel Independen

$\mathrm{y}_{\mathrm{i}}=$ Variabel Dependen

$\mathrm{n} \quad=$ Banyak Sampel

Dari hasil yang diperoleh dengan rumus di atas, dapat diketahui tingkat pengaruh variabel $\mathrm{X}$ dan variabel $\mathrm{Y}$. Pada hakikatnya nilai $\mathrm{r}$ dapat bervariasi dari -1 hingga +1 , atau secara matematis dapat ditulis menjadi $-1 \leq \mathrm{r} \leq+1$. Hasil dari perhitungan akanmemberikan tiga alternatif, yaitu:

a) Bila $\mathrm{r}=0$ atau mendekati 0 , maka korelasi antar kedua variabel sangat lemah atau tidak terdapat hubungan antara variabel $\mathrm{X}$ terhadap variabel $\mathrm{Y}$

b) Bila $\mathrm{r}=+1$ atau mendekati +1 , maka korelasi antar kedua variabel adalah kuat dan searah, dikatakan positif

c) Bila $\mathrm{r}=-1$ atau mendekati -1 , maka korelasi antar kedua variabel adalah kuat dan berlawanan arah, dikatakan negatif.

Menurut Vivi (2019) pedoman untuk menginterpretasikan hasil korelasi adalah sebagai berikut:

- $0.00-0.199=$ sangat rendah

- $0.20-0.399=$ rendah

- $0.40-0.599=$ sedang

- $0.60-0.799=$ kuat

- $0.80-1.000=$ sangat kuat

\section{Hasil dan Pembahasan}

Analisis korelasi digunakan untuk menganalisis hubungan antara dua variabel atau lebih yang bersifat kuantitatif. Meskipun korelasi digunakan untuk mengukur derajat hubungan, tetapi bukan untuk alat uji kausal. Sebuah variabel dapat dikatakan berkorelasi apabila perubahan sebuah variabel diikuti pula oleh perubahan variabel yang lain. Dengan demikian, tujuan dari analisis korelasi adalah untuk mengetahui apakah hubungan antara dua variabel signifikan atau tidak. Oleh karena itu, korelasi dapat dibedakan berdasarkan arah hubungannya, (Vivi Herlina, 2019).

Syarat adanya hubungan (korelasi) antara variabel produktivitas dengan variabel pendapatan adalah:

1. Jika Sig > 0.05 maka Ho diterima, artinya terdapat hubungan (korelasi) antara dua variabel tersebut.

2. Jika Sig < 0.05 maka Ho ditolak, artinya terdapat hubungan (korelasi) antara dua variabel tersebut.

Analisis korelasi pearson digunakan untuk mengetahui hubungan antara variabel produktivitas dengan variabel pendapatan secara linier. Korelasi person digunakan pada 
data yang berskala interval atau rasio. Adapun nilai korelasi product moment (pearson) antara variabel produktivitas dengan variabel pendapatan di Kabupaten Jeneponto disajikan pada Tabel 1:

Tabel 1. Hasil Uji Korelasi Pearson

\begin{tabular}{|c|c|c|c|}
\hline & & Pendapatan & Produktivitas \\
\hline \multirow[t]{4}{*}{ Pendapatan } & Pearson & 1 & .728 \\
\hline & Correlation & & \\
\hline & $\begin{array}{l}\text { Sig } \\
\text { tailed) }\end{array}$ & & .000 \\
\hline & $\mathrm{N}$ & 78 & 78 \\
\hline \multirow[t]{4}{*}{ Produktivitas } & Pearson & .728 & 1 \\
\hline & Correlation & & \\
\hline & $\begin{array}{l}\text { Sig } \\
\text { tailed })\end{array}$ & .000 & \\
\hline & $\mathrm{N}$ & 78 & 78 \\
\hline
\end{tabular}

Sumber : Data Hasil Penelitian Setelah Diolah, 2020.

Berdasarkan Tabel 11, diperoleh informasi nilai korelasi person antara variabel produktivitas dengan variabel pendapatan sebesar 0.728 . Oleh karena nilai korelasi berada di range 0.60 - 0.799 maka dapat disimpulkan bahwa hubungan antara variabel produktivitas dengan variabel pendapatan adalah kuat. Selanjutnya dilihat dari nilai signifikansi $0.000<0.05$ artinya Ho ditolak, artinya terdapat hubungan (korelasi) antara variabel produktivitas dengan variabel pendapatan dan dilihat dari nilai $r$ yang mendekati nilai +1 yaitu 1 yang artinya kedua variabel tersebut kuat. Hal ini sesaui dengan pendapat Sugiyono (2013) yang menyatakan bahwa, bila $\mathrm{r}=+1$ atau mendekati +1 , maka korelasi antar kedua variabel adalah kuat dan searah, dikatakan positif.

Produktivitas berpengaruh positif terhadap variabel pendapatan pada petambak garam, sebagaimana yang telah digambarkan pada tabel 10. Hal ini berarti bahwa produktivitas yang tinggi mempengaruhi tingkat pendapatan petambak garam, karena semakin banyak produktivitas yang dihasilkan maka tingkat pendapatan juga akan ikut meningkat. Hal ini sesuai dengan pendapat Herjanti (2007), yang mengatakan bahwa produktivitas merupakan suatu ukuran yang menyatakan bagaimana baiknya sumber daya diatur dan dimanfaatkan untuk mencapai hasil yang optimal. Produktivitas dapat digunakan sebagai tolak ukur keberhasilan suatu industri atau UKM dalam menghasilkan barang atau jasa. Sehingga semakin tinggi perbandingannya, berarti semakin tinggi produk yang dihasilkan.

\section{Kesimpulan}

Berdasarkan nilai korelasi dan nilai signifikan pada produktivitas dan pendapatan dihasilkan nilai yang kuat artinya terdapat hubungan (korelasi) antara variabel produktivitas dengan variabel pendapatan dan dilihat dari nilai $r$ yang mendekati nilai +1 yaitu 1 yang artinya kedua variabel tersebut kuat dan memiliki hubungan satu sama lain.

\section{Ucapan Terimakasih}

Penulis menghaturkan terima kasih dan sembah sujud kepada Allah SWT yang telah memberikan segala kekuasaanNya dan kemurahan-Nya sehingga penulis diberi kesehatan agar menyelesaikan tesis ini, dan tidak lupa penulis ucapkan terima kasih yang sedalam dalamnya kepada kedua orang tua penulis yang tercinta dan tersayang Ayahanda Baso Badullah, S.Sos dan Ibunda $\mathrm{Hj}$. Aspadaniati yang telah memberikan kesempatan yang kesekian kalinya untuk sekolah dengan bantuan biaya dari mereka, biaya tidak cukup bagi penulis untuk menyelesaikan sekolah tetapi dengan adanya doa yang tak hentihentinya diberikan oleh mereka sehingga kesuksesan dan keberhasilan penulis menyelesaikan pendidikan dijenjang magister (S2) dan terimakasih juga kepada kedua pembimbing penulis Dr. Sri Suro Adhwati, SE., M.Si selaku pembimbing utama dan Dr. Ir. Aslina Asnawi, S.Pt., M.Si., IPM selaku pembimbing anggota yang layaknya seorang ibu, yang tetap setia membimbing penulis hingga memperoleh gelar magister dan selalu menasehati dan memberi motivasi kepada penulis untuk selalu percaya diri dan optimis serta dengan sabar dan penuh tanggung jawab meluangkan waktunya ditengah pandemi Covid-19 baik via chat whatsapp, via email maupun secara langsung sampai tulisan (tesis) ini selesai dengan baik, maafkan leo yang banyak maunya ini ibu.

\section{Daftar Pustaka}

Astutik, M. A., Nurmalina, R., \& Burhanuddin, B. (2019) Analisis Status Keberlanjutan Pengusaha Garam di Tiga Wilayah Pulau Madura. Jurnal Agribisnis Indonesia, 7(1), 13-26

Dinas Kelautan dan Perikanan Provinsi Sulawesi Selatan. (2017). Laporan Tahunan Kelautan dan Perikanan Sulawesi Selatan 2016. Makassar: Dinas Kelautan dan Perikanan Provinsi Sulawesi Selatan.

Dinas Kelautan dan Perikanan Provinsi Sulawesi Selatan. (2020). Laporan Tahunan Kelautan dan Perikanan Sulawesi Selatan 2019. Makassar: Dinas Kelautan dan Perikanan Provinsi Sulawesi Selatan

Saga Neli Riyanti, D. A,. Satriawan, I.K,. \& Bayu Sadyasmara, C. A. (2019). Analisis Pemasaran Garam Kasumba di Kecamatan Dawan, Kabupaten Klungkung. Jurnal Rekayasa dan Manajemen Agroinsdustri, 7(2), 169

Effendy, M., Zainnuri, M. dan Hafiluddin. 2014. Intensifikasi Lahan Garam Rakyat di Kabupaten Sumenep. Program Studi Ilmu Kelautan Universitas Trunojoyo Madura: 22-43

Wirawan, Jerome. (2017). Indonesia negara maritim tapi mengapa harus mengimpor garam?. BCC News Indonesia. Diakses 20 Januari 2020. Available from: http://www.bbc.com/indonesia/indonesia- 40792179.

Wiryati, G., Sunaryo, A., Susilawati, T., Leilani, A., Perikanan, J. P., \& Perikanan, S. T. (2019). Potret Sistem Agribisnis Pengolahan Hasil Perikanan di Pesisir Pantai Selatan Kabupaten Garut. Jurnal Penyuluhan, 15(2), 266-274 